\title{
Retrospective analysis of the land cover and the land use changes in the Dragoman Marsh Area Over a period of 50 years (1965-2015) by using remote sensing data and GIS
}

\section{Stefan GENCHEV ${ }^{1}$ (D)}

${ }^{1}$ National Institute of Geophysics, Geodesy and Geography, Department of Geography, Sofia, Bulgaria

ORCID: 0000-0002-7080-5678

\section{ABSTRACT}

The Dragoman marsh is a unique example of ecosystem recovery for the territory of the Republic of Bulgaria. It is a part of protected area, included in the NATURA2000 ecological network. In this paper, the author will track the dynamics of the change in water body area boundaries over a 50 years period (1965-2015) by using aerial photos, high resolution satellite imagery, large-scale topographic maps, and data under the CORINE LAND COVER project (containing information on land cover and land use on the area of the selected natural site). This article also aims to present some bad practices of the past, which led to significant changes in the condition of the Dragoman marsh. Proper management and restriction of inappropriate human intervention are crucially important for the conservation of important plants and ornithological species inhabiting the place.

Keywords: Wetland area, Recovery, NATURA2000, habitat protection. 


\section{INTRODUCTION}

Water is the key factor on which environmental conditions in ecosystems such as wetlands depend, as well as the dwell animal and plant species. Wetlands are an important part of the global ecosystem because their major role in maintaining the biodiversity of plant and animal species (invertebrates, fish, amphibians, reptiles, birds and mammals). Taken together, these areas occupy proximally between 4 and $6 \%$ of the surface of planet Earth. The anthropogenic pressure exerted on wetlands in recent decades and the ensuing problems are a cause for serious concern (Keramitsoglou et al, 2015). The draining of wetlands and their transformation into arable land becomes more widespread phenomenon in the modern world. These areas contribute to the development of important cultural values in different regions of the world. (https://www.bsb...) .As indicated by Mitsch and Wu (1995) in their study, wetlands are a serious carbon regulator in the biosphere. This fact not only places the wetland areas among the important conditions for enhancing biodiversity, but also proves that wetlands are a potentially important component in the climate change process.

The proper management and conservation of these natural ecosystems has been the subject of study by various groups of scientists over the last two decades (Spanhove et al, 2012). The process of mapping such areas is often a complex task, at least because of the frequent change in the size of the water mirrors of the study area (Keramitsoglou et al, 2015). Historical changes in the size and condition of the biophysical components constitute an essential element in the present study. Mapping the size of their changes is particularly important for tracking the development of the studied ecosystem and its recovery after years of anthropogenic interference.

As a reference point in the study is taken the year of 1965 when the wetland drainage process is most active. The final time point is in June 2015, when the study area is completely restored in spatial aspect and also is in the midst of spring flood.

\section{STUDY AREA, USED DATA AND IMPACT OF THE CHANGES OVER THE ENVIRONMENTAL BALANCE}

Wetlands play an important role in restoring water supplies and groundwater recharge. They serve as a natural depot - a filter for purification of the water passing through them. On the other hand, they reduce the risk of flooding by absorbing much of the surface runoff. Unfortunately, their conversion to arable land and their worldwide drying-up have led to the disappearance of $50 \%$ of the peatlands, marshes, coastal lakes, riparian and floodplains of the rivers. Due to a number of agricultural activities carried out directly within their borders, wetlands are a source of food and a number of other agricultural products such as herbs, fuels and more. Wetlands play an important, albeit indirect effect on agriculture. They provide conditions for the development of fruitful soils and provide a source of good quality water.

At the beginning of the 20th century, wetlands occupied about $2 \%$ of the territory of Bulgaria. Over the years these areas have decreased about 20 times. Many of them have been drained without appreciating the role they played in ecosystem balance. Following this trend, in the 1930s, the construction of 11 drainage channels and a pumping station began, through which the systematic draining of the Dragoman swamp was carried out. After 1990, agricultural activities in the area gradually began to decrease and by 2000 water pumping had ceased. This leads to the gradual recovery of the natural ecological status of the wetland. Under the patronage of the Ministry of Environment and Water, and local authorities and with the active participation of a number of non-governmental organizations, consecutive conservation activities in the region began. This wetland is about to become the only naturally restored area of this nature in the country (https://www.bsb...).

The Dragoman marsh is laying at the bottom of the effluent-free valley surrounded by mountain ridge of Chepan northwards, and Rayanovsko karst field eastward. From the south it reaches the mountain hill "Tri Ushi" and in west direction it touches the town of Dragoman. The altitude of the marsh is $701 \mathrm{~m}$ above sea level and it is located in the lowest elevations of the hollow described above. During spring flood, the area of the water body covers an area of about 360 ha. The Dragoman swamp is the largest karst self-recovered wetland in Bulgaria (fig.1). 


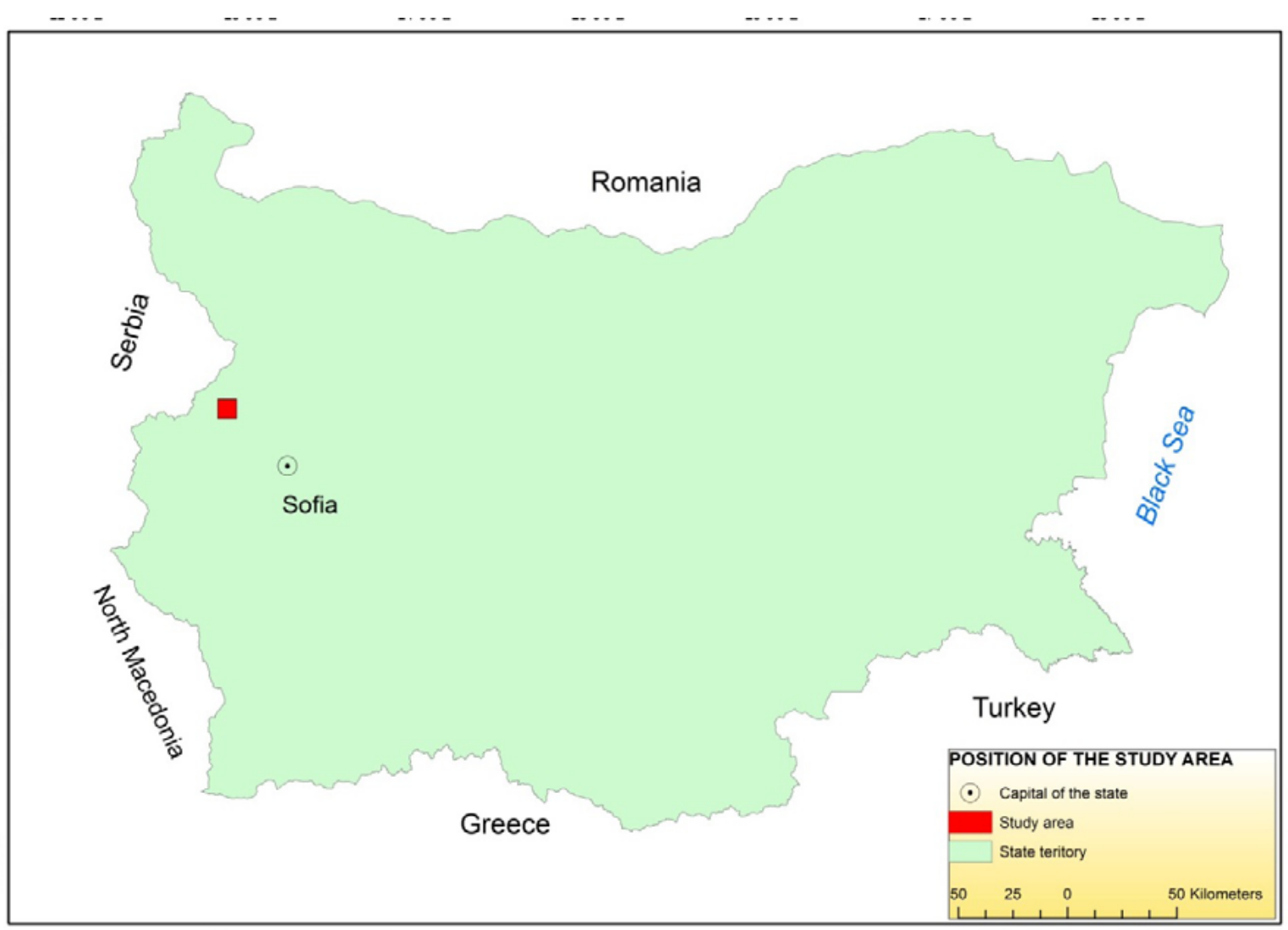

Figure 1: Mapp of the position of the study area within the state territory.

The first attempts to drain the Dragoman Marsh date back to the 1920s, and for the first time it was drained in the 1930s.

The data used for the study includes aerial photos from 1965, large-scale Bulgarian topographic maps at M1:5000 from 1970, largescale Soviet topographic maps from 1986 at M1:50000, Corine Land Cover data from 1990, 2000 and 2006, as well as a high-resolution satellite image obtained from a Pleiades-1A / B sensor (with a spatial resolution of $0.5 \mathrm{~m}$ ) from 2015. As a result of the data processing for the task of the study were compiled the following eight maps.

As can be seen from the surveyed topographic maps and aerial photographs, in 1965 the Dragoman swamp was practically completely drained and its territory was occupied by arable land and meadows (fig.2). 


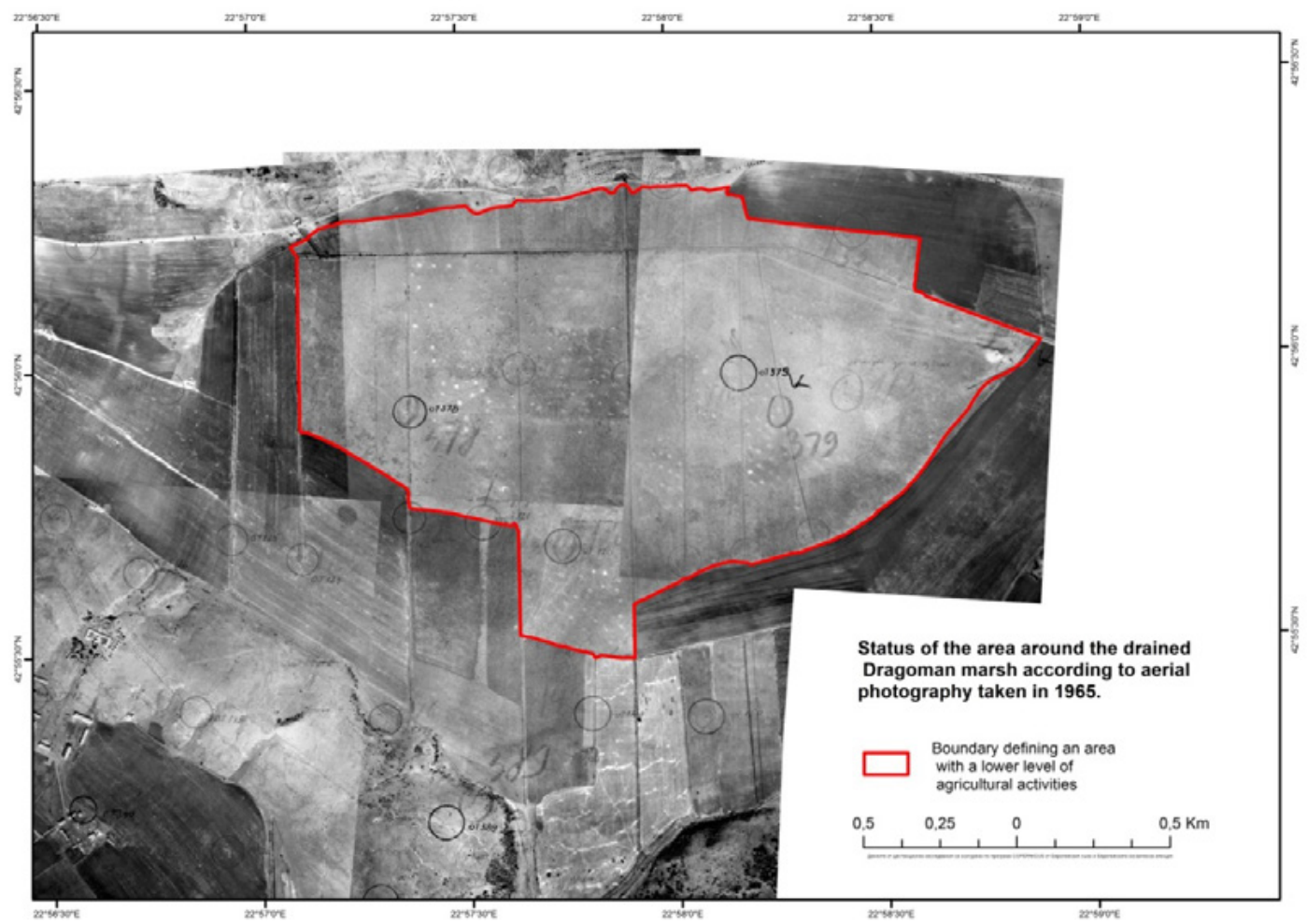

Figure 2: 1965 situation of the area according to the aerial photographs.

Agricultural machinery captured on the aerial photographs, in sections of the swamp which by 2015 are flooded and virtually impassable, is proof of this statement (fig.3).

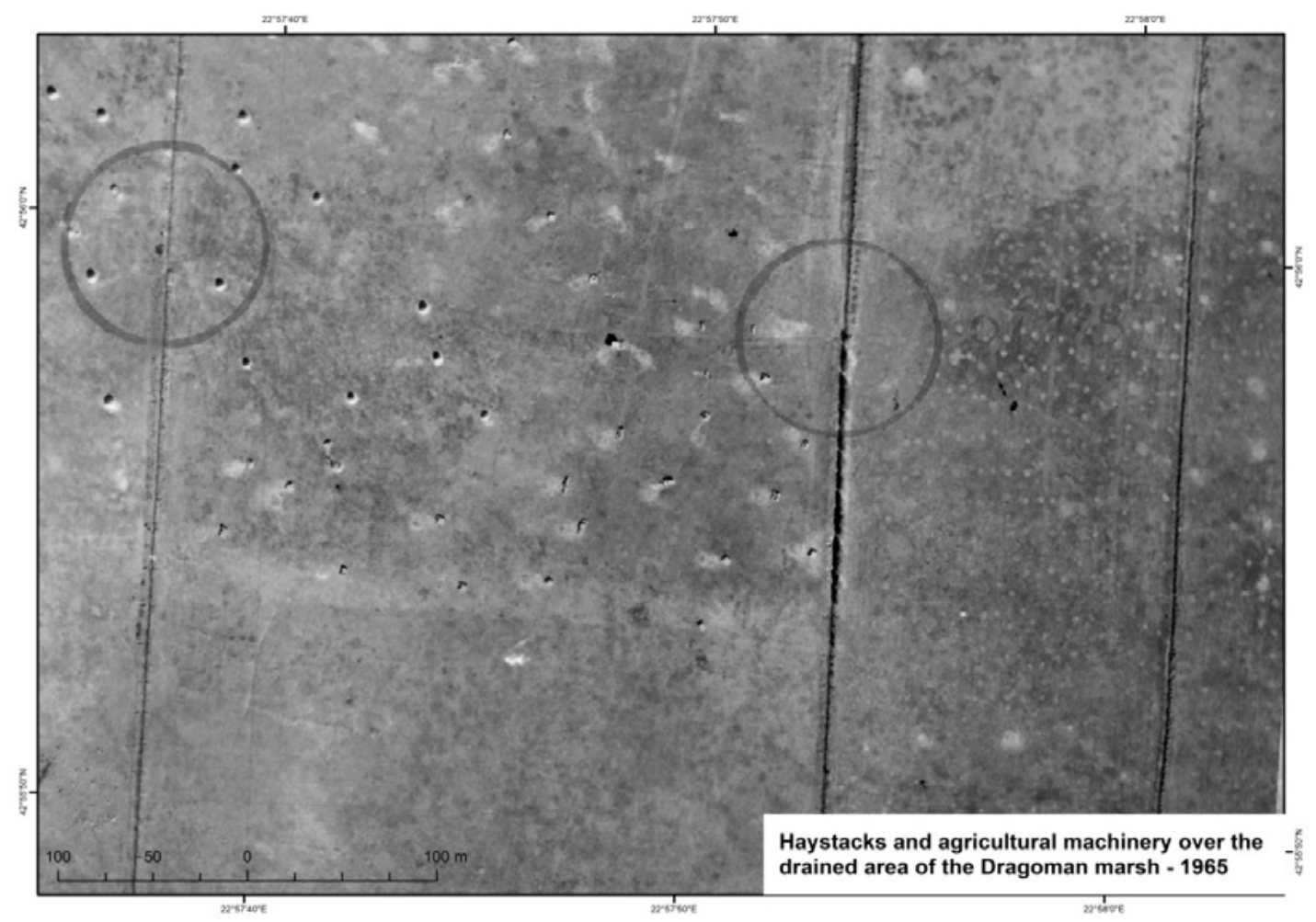

Figure 3: Map of a section of the drained marsh covered with haystacks and agricultural machinery - 1965. 
Aerial photographs show that the central parts of the marsh that had been dried up at that time (1965) were used for haying and grazing. Clearly distinguished from the aerial photographs are harvested bowls of cut hay and herds grazing livestock (fig.4).

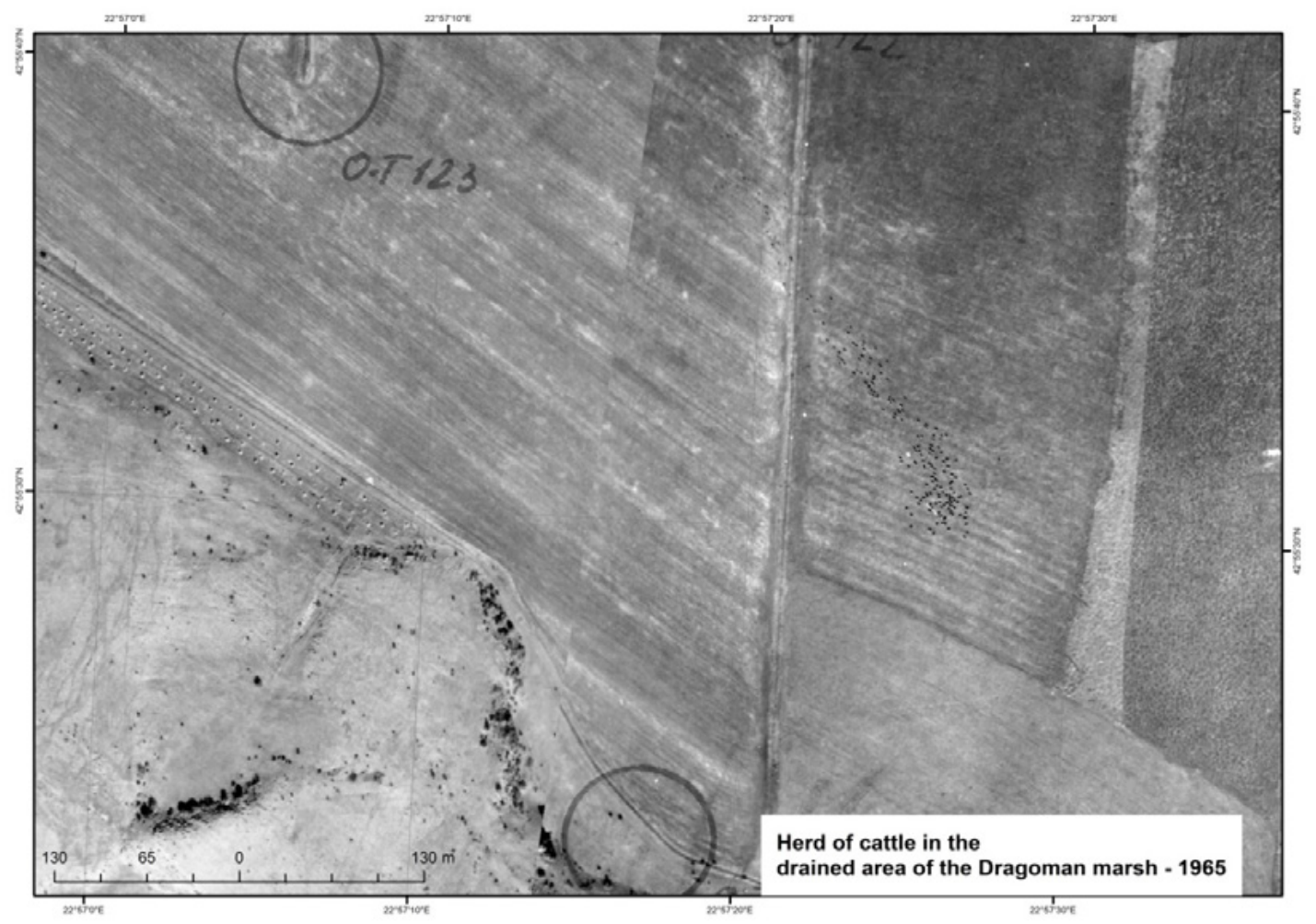

Figure 4: Map of a section of the drained marsh with herds grazing livestock - 1965 .

The constant wetland drainage activities have yielded results and in practice for several decades the only areas occupied by water in the ex-marsh were the drainage channels.

The study area is part of one of the biggest negative karst forms in Bulgaria - the Rayanovsko karst field. Its catchment area (on the Rayanovsko karst field) is $28 \mathrm{sq}$. km. Dragoman marsh plays an important role in the hydrogeological conditions in the mentioned karst ecosystem. On one hand the marsh drains partly the karst mountain massif of Chepan, which is located just north of it. On the other hand the accumulated waters of the swamp feed Opitsvet - Bezden springs system, setting a constant water level of the plateau massif above them (Mihailova B. et al, 2008). Drainage of water quantities is done through contact and overflow karst springs. The strong fluctuations in their flow rates are typical. Along with other karst areas, karst with an abundance of surface forms is also presented here (Radev, 1915).

\section{RESULTS AND DISCUSSION}

The consequences from the loss of wetlands and associated functions and values of ecosystems are often irreversible (Mitsch W., J. Gosselink, 2000). As a result of the drainage operations performed in the study area, many rare plants and animals - the water lily (Nymphaea alba), the lesser bladderwort (Urticularia minor) and the slender pondweed (Potamogeton pusillus) - were lost. The insectivorous waterwheel plant (Aldrovanda vesiculosa) and caldesia (Caldesia parnassifolia) are permanently lost from the territory of the country. They have been presented only in the study area, and as a result of systematic drying they completely disappear from the territory of Bulgaria. These loses of wetland are a serious blow to the ornithological diversity in our country. Many bird species - cranes, herons and ducks, lost their natural habitat (https://www.bsb...).

According to the results of the study, the areas occupied by the swamp vary from 137.96 ha (1990) fig.5 and up to 369.9 ha (2006) fig.6. 


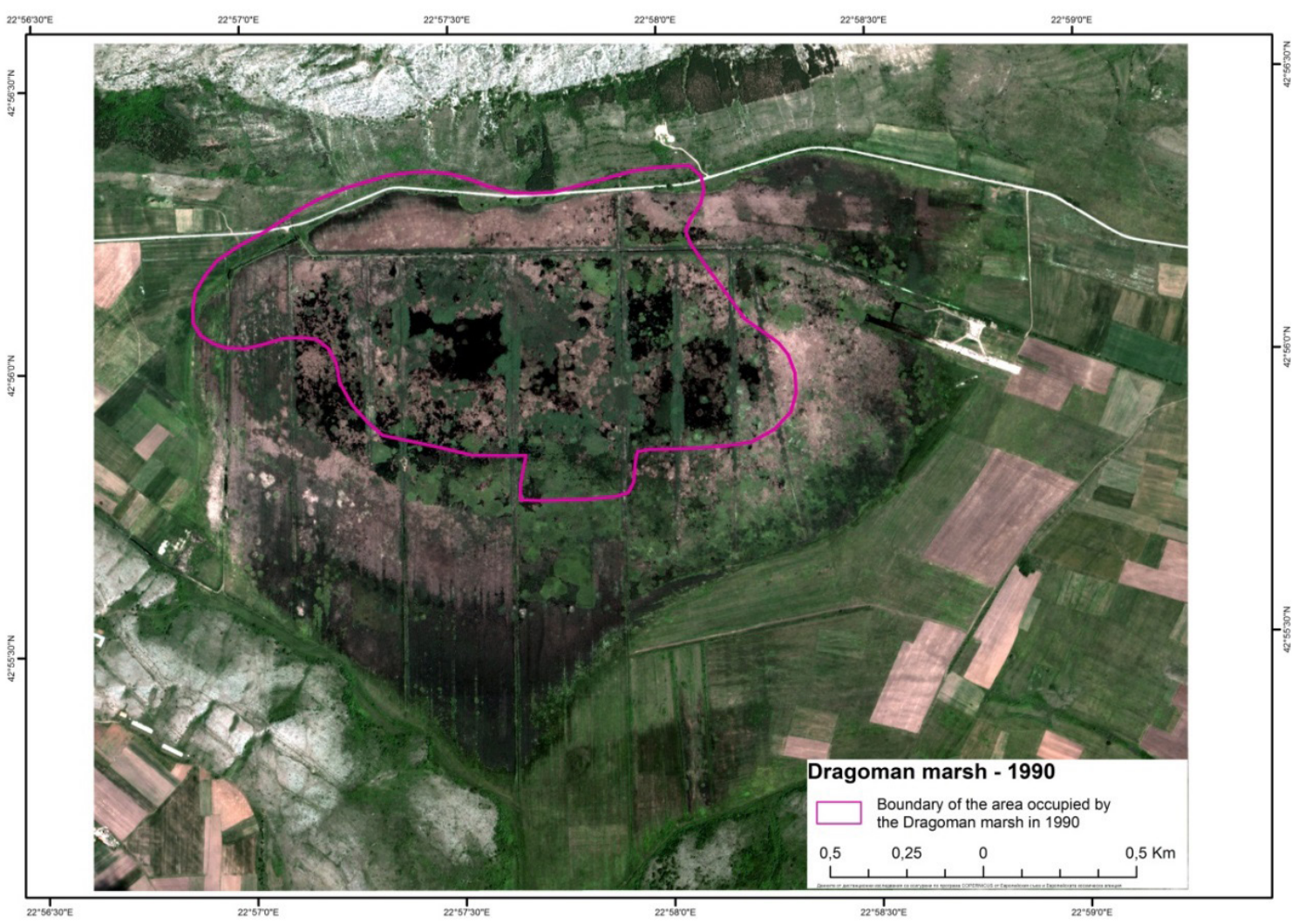

Figure 5: Map of the area occupied by the Dragoman marsh in 1990.

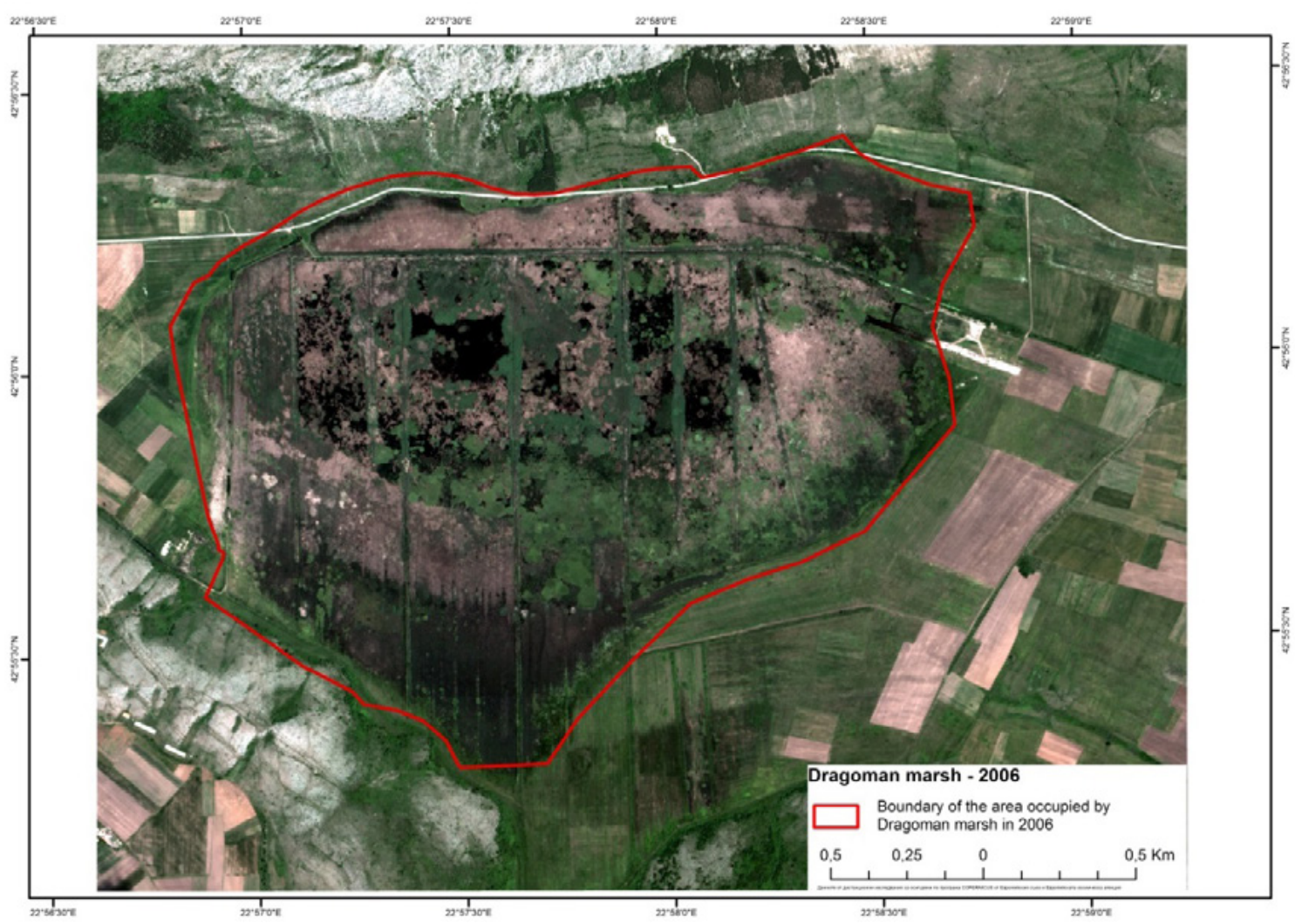

Figure 6: Map of the area occupied by the Dragoman marsh in 2006. 
According to the aerial photo taken in 1965, the swamp was transformed into a wet meadow with a total area of 232.8 ha on which agricultural activity is carried out (fig.2). No water mirrors were detected at that year. In 1986, the wetland area was 158.2 ha (fig.7).

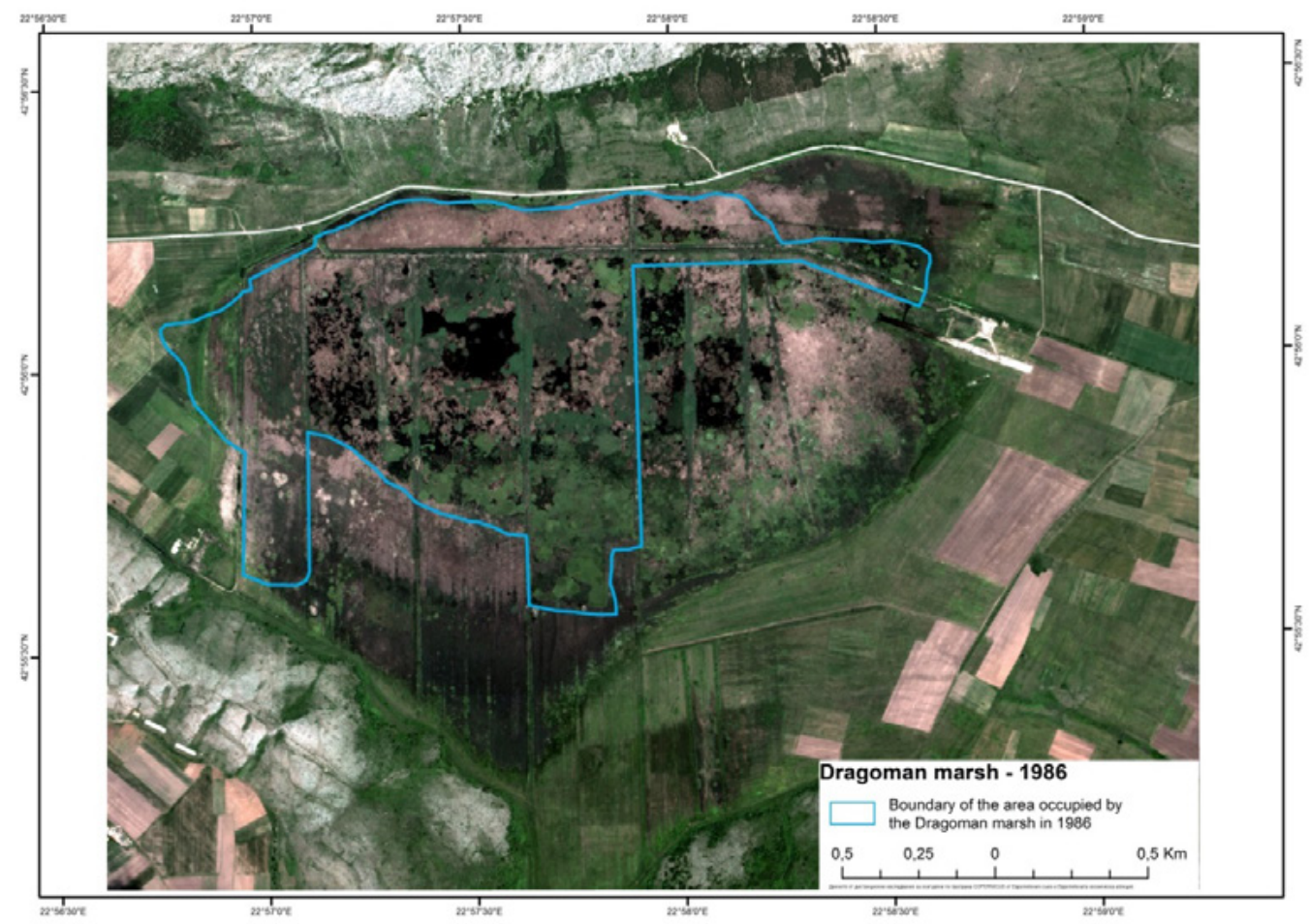

Figure 7: Map of the area occupied by the Dragoman marsh in 1986.

In the year 2000, the drainage was completely stopped and the area of the water body at that time had grown to 193.52 ha, fig.8.

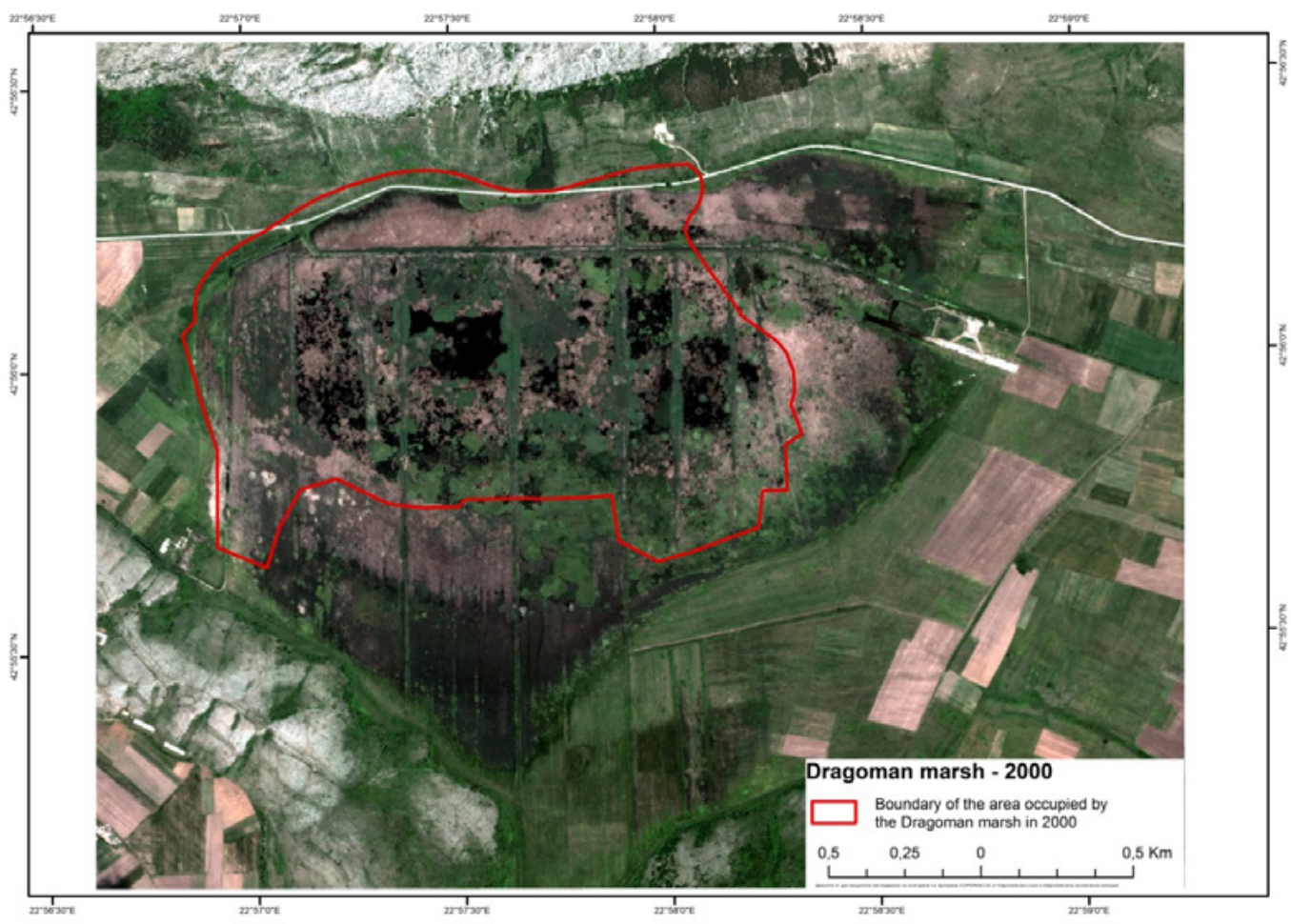

Figure 8: Map of the area occupied by the Dragoman marsh in 2000. 
According to the high generalization of the Corine Land Cover data, for most relevant value of the marsh area should be taken the area covered by the marsh in June 2015 (fig.9). Even though the CLC 2006 data shows that in the year of 2006 the swamp area is bigger than in 2015, it is not true. The territory between the road and Chepan mountain was recognized as a swamp territory according to the CLC 2006 data, but due to the specifics of the terrain, and the hillslope in particular it is impossible for the marsh waters to cross the road and flooded the hillslope.

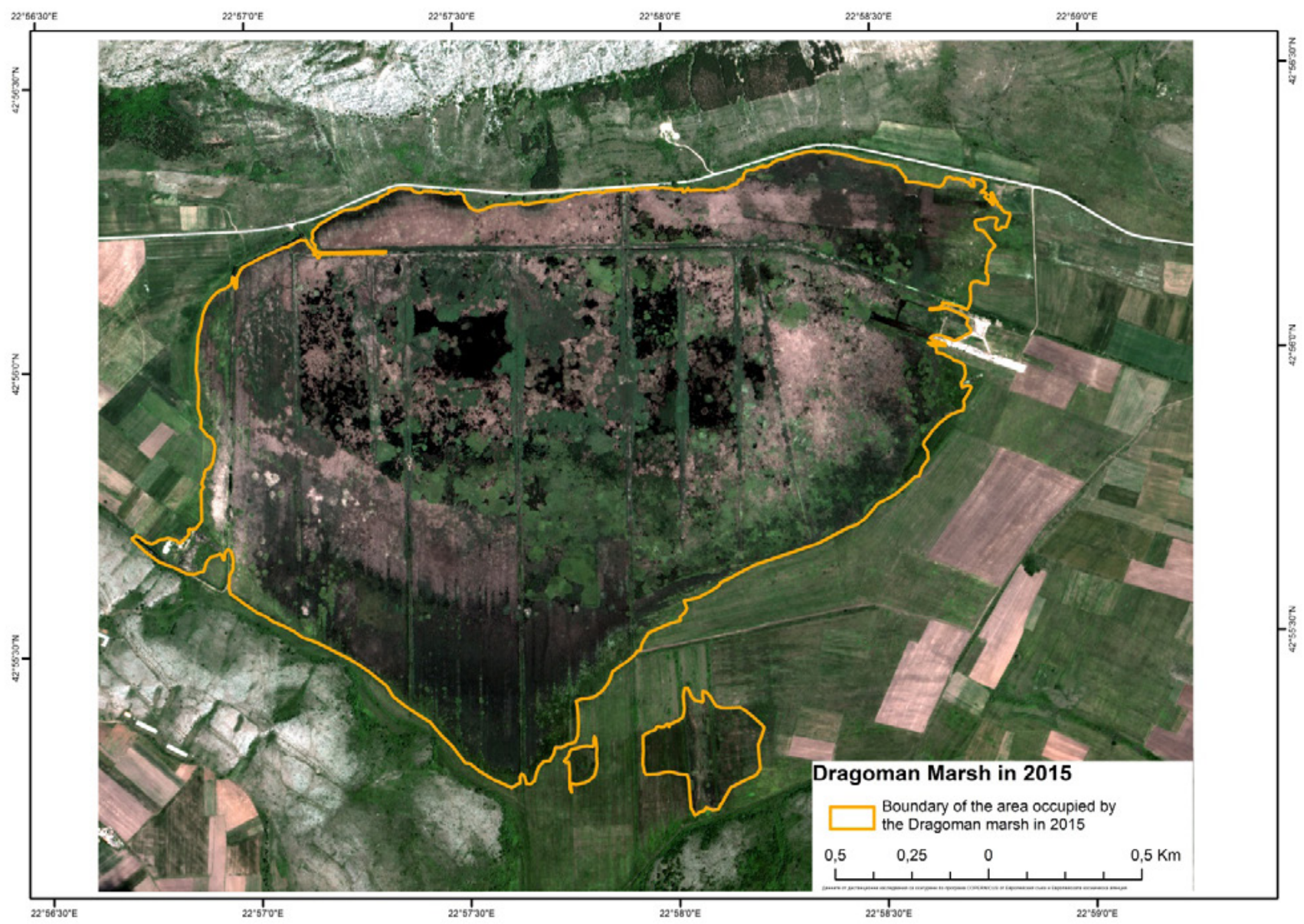

Figure 9: Map of the area occupied by the Dragoman marsh in 2015.

Area calculations were performed by using the ArcMap 10.3 software.

Table 1: Area covered by the Dragoman marsh during the years of the survey.

\begin{tabular}{lllllll}
\hline Year & $\mathbf{1 9 6 5}$ & $\mathbf{1 9 8 6}$ & $\mathbf{1 9 9 0}$ & $\mathbf{2 0 0 0}$ & $\mathbf{2 0 0 6}$ & $\mathbf{2 0 1 5}$ \\
\hline Marsh Area (ha) & $0(232.8)^{*}$ & 158,2 & 137,96 & 193,52 & 369,9 & 361.1 \\
\hline $\begin{array}{l}\text { *The given value in the brackets shows the area free of active agricultural activities. There is none indication of marsh area in that } \\
\text { moment. }\end{array}$
\end{tabular}

In our days, the Dragoman marsh is included in two Natura 2000 protected areas - Dragoman Protected Site and Rayanovtsi Protected Site. In the year of 2012, Bulgaria's 11th wetland of global importance was announced - the karst complex Dragoman marsh. The complex includes the last preserved karst marshes in Bulgaria - Dragoman marsh and Aldomirovsko marsh, the wet meadows around the marshes and the wet meadows between the villages of Tsurklevtsi and Buchin prohod. It is the largest wetland area of global importance for the country (http://balkan...). 


\section{CONCLUSION}

The restoration of the Dragoman marsh in spatial terms is practically a completed process. Although it is under the protection of at least two protected areas, a number of problems persist. The most harmless among them is poaching, which mainly consists of unregulated fishing. The outpouring of sewage near the swamp is partially solved in the last decade, but still large amount of waste water of the Dragoman town sewage system go directly into the wetland. Reintroduction of the lost plant and animal species goes slow, although in the last $10-15$ years the majority of the representatives of the ornithological fauna successfully adapt to the recovered water body.

Acknowledgement \& Grant Support: This work was supported by the Bulgarian Ministry of Education and Science under the National Research Programme "Young scientists and postdoctoral students" approved by DCM \# 577 / 17.08.2018.

\section{REFERENCES}

Keramitsoglou, I., Stratoulias, D., Fitoka, E., Kontoes, C., Sifakis, N., (2015),

A transferability study of the kernel-based reclassification algorithm for habitat delineation; International Journal of Applied Earth Observation and Geoinformation

Volume 37, Pages 38-47;

Mitsch, W.J., Wu, X., (1995), Wetlands and global change;

Soil Management and Greenhouse Effect, Advances in Soil Science, CRC Press, Boca Raton, Florida;

Spanhove, T.L., Vanden Borre, J., Delalieux, S., Haest, B., Paelinckx, D., (2012) Can remote sensing estimate fine-scale quality indicators of natural habitats? Ecol. Indic., 18, pp. 403-412;

Mitsch, W.J., Gosselink J.G., (2000), The value of wetlands: importance of scale and landscape setting Ecol. Econ., 35 (1), pp. 25-33;

Михайлова, Б., К.Костов, М.Данаилова, А.Бендерев, Особености и развитие на карста във водосбора на Опицвет-безденските извори, Конференция „Изследване и опазване на карста и пещерите“ по случай 50 години Студентски пещерен клуб „Академик“- София, 24 окт.2008г., гр.София;

Радев Ж., 1915, Карстови форми в Западна Стара планина. - Год. СУ., Ист.-фил.факултет, 10 - 11: 1 - 149;

https://www.bsbd.org/bg/index_bg_6277243.html

http://balkani.org/wetlands/dragoman_marsh/ 